\title{
Pluralism Religious Education Implementation In Public Schools \\ (Case Study Religious Regular Public Schools Religious in Magelang City)
}

\author{
Indira Swasti Gama Bhakti ${ }^{1}$, Tri Agus Gunawan ${ }^{2}$ \\ \{indiraswastigb@gmail.com ${ }^{1}$, gunawan5858@gmail.com ${ }^{2}$ \}
}

The Program of Jurisprudence, Faculty of Social And Political Science, Tidar University, Kapten Suparman Street 39 Magelang, 56116, Indonesia ${ }^{1}$, The Program of Jurisprudence, Faculty of Social And

Political Science, Tidar University, Kapten Suparman Street 39 Magelang, 56116, Indonesia ${ }^{2}$

\begin{abstract}
Character education and religious education as an icon of unifying the, as important this is because the nature of plurarisme. which is embraced by Indonesia country. Education in schools in Indonesia admitted subjects religious education which is one of the lessons are required and accepted by the students. The role of the head of school at public schools for students from religious is the pure religion and bring differ very have prepared education teachers that is suitable for the students and prepared a form of the willingness of at the beginning of students who registration by the parents of the religious education lessons that will be allocated to students in accordance with a characteristic religion the school. Obstacles facing any by the head of schools on the matter of this is the lack of a means of the special room which can be used in religious education learning activities, setting the schedule the teaching and teachers teachers because the separation hours disturb the learning and teaching who are devout and the limited number of other human resources teachers for certain religious subjects.
\end{abstract}

Keywords: Implementation, Pluralism, Religious Education.

\section{Introduction}

Character education for students is needed in education sector. Religious education icon important as unifying nations, this is because the nature of plurarisme which is embraced by country .There are six religion which currently recognized by the state is Islam, Christian, Catholic, Hindu, buddhist and konghucu .Through the provision of subjects education religion can be used as a man fulfilling the essence .Religion and live believe is a which the essence or important now needs everyone.

Education in schools in indonesia admitted subjects education religion in the curriculum and subjects religious education is one must remember that should appear and accepted by the students .Through a lesson religion and religion teachers different from typical religious schools of typical religious and the autonomy of the school.Undang-undang nomor 20 tahun 2003 on the national education system ( hereinafter called UUSISDIKNAS ) article 12 paragraph 1 point a letter, said that "every students at any a unit of education deserves religious education in accordance with the religious their and taught by educator in faith." Through this article clearly stated that it is not just a public school but also in private schools, each student deserves religion studies in accordance with his religion must be fulfilled, but with this schools to provide teachers religion to all students in accordance with their religion. 
The regulation on public schools there are religious in article 55 UUSISDIKNAS namely "community education right to carry out community based on a formal education and in accordance with the peculiarities of, non formal religion a social environment, and culture for public interest." In addition arranged also in Peraturan Pemerintah Republik Indonesia Nomor 55 Tahun 2007 about education of religion and religious education, article which reads 3 "Each unit, education in all the way the level of, and kind of compulsory education. held religious education." based on the description above and to know about religious pluralism public schools on the implementation of different religious education with a characteristic, the school so that researchers decided to take on titles "Pluralism Religious Education Implementation In Public Schools (Case Study Religious Regular Public Schools Religious in Magelang City).”

\section{The Issue}

Based on the explanation in the background problems and identification problems above, so subject matter in this research can formulated as follows:

(1) How the role of the head school in public schools religious in the city magelang to students who have different religious with a characteristic school ?

(2) What obstacles of school principals in the education religion in the regular public schools religious magelang city?

\section{The Purpose of The Research Objectives}

Is to understand the extent of the role of school principals to public schools in the city magelang against religious students who have different religious school with a characteristic; and to know what happened with the principal in the implementation of the religious education at primary school in the city magelang common religious.

\subsection{Literature Review}

\section{Implementation}

Implementation according to KBBI (dictionary of indonesian) is implementation or application [1]. And the act or a general sense is a plan which has been arranged in the careful and detailed. Not only just activity, implementation is a planned activity and be serious too you to reach reference to certain objectives of the activities [2] .

Implementation is an act or the conduct of a plan had already been prepared in hand and detail. Usually done after implementation is considered perfect planning. According to Nurdin Usman, implementation is rises upon an activity, action, the act of a system, and the mechanism implementation activity, rather than but an activity that planned and to achieve objectives of the activities [3] .

\section{The concept of pluralism}

Pluralism (English: pluralism), consisting of two words (plural $=$ diverse) and (isme $=$ understand ) which means understand for the diversity [4]. Pluralism also can mean willingness to receive the diversity (a plurality), it means to live in tolerant at the stage of people of a different tribe, the religion, customary, to view of life. Pluralism implies to that action which ended up at recognition freedom of religion, freedom of thought, or freedom looking for information, pluralism needed so as to reach maturity from personality someone and / or group of people. 
Based on on the have understood that the essence sense plural said, plurality, and pluralism is the same, equally containing the diversity of sense, the diversity, keberbagaian, and kebinekaan. Said "plural" used to showed an adjective, said "plurality" used to show the state or fact compound watercolor prints, and the pluralism worn to indicate view or informed about the diversity [5] .

- Religious Pluralism

Religious pluralism is a term specialized in the religious studies. As "special terminology", the term this cannot be seen carelessly, for example be likened to the meaning of the term tolerance, mutual respect and so on. As one understand (ism ), to discuss their views of religious existing, the term of "religious pluralism" has been a long discussion among scientists in the study religions (religious studies).

\section{The position of religion in curriculum education for the primary education}

The subjects religious education in the curriculum and the subjects are national and must be proven in article 6 paragraph 1 government regulation republic of indonesia no 13 years 2015 revision of the two top government regulation no 19 years 2005 on national education standards explained that the curriculum to a kind of public education, vocational, and specifically at the level of primary and secondary education consists of :

a. the religious subjects and noble moral;

b. the subjects of citizenship and personality;

c. ...... etc.

And paragraph (2) said that forms of education curriculum to religious consists of the formal subjects determined based on religious education targets. Religious education in national education arranged specifically through Government Regulation The Republic Of Indonesia No 55 Years 2007 about religious education and religious (called PP No. 55 years 2007) on:

Article 1 number ( 1 ) the education religion education and forming attitude, the personality, and skill in the students had religion, conducted at least through subjects / college in all lines, level, and forms of education.Learning system of your students or students set right to get matter religious education you mentioned article 4 ( 2 ) pp no. 55 year 2007 every students on a unit education in all lines, level, and forms of education religious education religion right according to naught and taught by educator who friends; and articles and 12 ( 1 ) a letter in which every in any unit of education students receive religious education in accordance religion naught and taught by educator who friends.

The schools as a unit of education arranged on article 4 paragraph ( 3 ) until ( 7 ) PP

No. 55 Years 2007 :

(3) each unit organized education provides a religious education;

(4) of education could not provide a held religious education as referred to in paragraph (3) can cooperate with the level of education or religious education in the community to implement for learners. religious education;

(5) each unit and education provides a chance for students to conduct worship under the terms of religion followed by students;

(6) place conduct religious worship as referred to in paragraph (5) can be room in or around such a unit of education can be used students running people;

(7) A unit of certain religious education who are not building a house religious worship other than those in accordance with a characteristic religion a unit of education concerned. 


\section{Methodology}

\section{Type Used The Research}

The research used types or methods descriptive qualitative research. Moleong says that the descriptive research is trying to express a problem as it was, shall therefore researchers limited expressing the facts and do not use is hypothesized. Descriptive research to describe exactly but to individual and social conditions arising in society to be as a research [6] .

\section{Informants Research}

On the qualitative study, researchers entering certain social situations, making observations and interview to those whom know about these social situation. The determination of the source of data on people who were interviewed conducted in a purposive, which is chosen with consideration and a particular purpose. The informant in this study is The Principal Grounds Of Common Religious Magelang City.

\section{Research Locations}

The research areas are in regular public schools religious in Magelang City.

\section{The Technique Of Data Collection}

Data collection techniques used in this research was:
a) observation;
b) interview;
c). Documentation

\section{The Data Analysis Techniques}

In analyzed data, researchers based on the steps will the following:
a) data collection;
b) editing;
c) interpretation of data.

\section{Finding and Discussion}

\subsection{The Results of Research}

The data was obtained from the research team's interview with Mrs. Ngatiyem and Mr. Muh. So'im as the Principal of SDN 7 Magelang and the teacher of SDN 7 Magelang, that most of the students at SDN 7 Magelang are Muslim, there are some Christian, Catholic and Hindu students. Mrs. Ngatiyem as the principal facilitates non-Islamic students to obtain religious education in accordance with the beliefs adopted by their students. When teaching and learning activities (KBM) Islamic education subjects, students who are other religions have activities to learn outside the classroom.

And, the class schedule of students' religious education subjects with Christianity, Catholicism and Hinduism adjusts the schedule of the teachers provided at SDN 7 Magelang. Because, teachers of religious education subjects other than Islam are presented from the outside. The classrooms used for non-Islamic students learning to teach religious education subjects are located in laboratory rooms because there are no special classrooms available for the implementation of subjects outside the classroom. The data obtained from the interview with 
Mr. Yusup Tata Wibawa as the Principal of Tarakanira Magelang Elementary School is about students who are religious outside of Catholicism and that religious teachers are not provided for them. Students who are religious other than Catholicism can participate in teaching and learning activities of Catholic religious subjects. This has been going on since Tarakanita Elementary School was established until now and there have been no problems in its implementation. The principal of SD Tarakanita Magelang also said that the provision of Catholic religious education subjects is a means to increase students' knowledge about what Catholicism is, what knowledge students get about Catholic religious education subjects and not the "doctrinalization" of Catholicism towards students. This was always conveyed by Mr. Tata Wibawa as the Principal of Tarakanita Magelang Elementary School. And, many parents who are religious other than Catholics entrust their children's education in Tarakanita Elementary School. This can be seen from the number of religious students outside christianity, namely $15 \%$ of the 451 students of all tarakanita elementary school students. There are 14 classes with approximately 28 students each.

Tarakanita Elementary School did not force parents of non-Christian students to attend Tarakanita Elementary School, all submitted back to the parents' decision. Mr. Tata Wibawa said "our term is like selling, mas mbak. There are buyers we serve, otherwise so buying yes is okay. We're not imposing. Because our flag is the Catholic flag. People also know about it, when going to send their children must know that the religious education that will be given by us is Catholic religious education and not others, in the sense that we are not the one who adjusts the students but the prospective students who adjust to the flag of our school. There are many religious school options in Magelang, such as Christian Elementary School, Pentecostal Elementary School for Christians, Mutual Elementary School for Muslims and Tarakanita Elementary School for Catholics."

\subsection{Discussion}

\section{The Role of Principals in Religious Public Schools Towards Students Who Have Different Religions}

The rules regarding the system of organizing religious education are very clear, although there are still differences in the practice of implementation. UUSISDIKNAS Article 12 paragraph (1) mentions the religious learning system, namely:

(1) "Every student in each educational unit has the right to: a) Get religious education in accordance with the religion it embraces and is taught by religious educators."

Explanation of Law 20/2003 article 12 (1) namely "Educators and/or religious teachers who are religious with learners are facilitated and/or provided by the Government and/or Local Governments in accordance with the needs of educational units." The role of the Principal of SD Negeri 7 Magelang is to provide teachers for students who are religious other than Islam. Bring in religious education teachers according to the needs of the school based on the religion embraced by the students.

Speaking of the context of school autonomy, it is known that every religious public school has the right to offer only religious lessons according to its characteristics. For example, Catholic schools have the right to offer only Catholic religious lessons. Christian schools only offer Christian religious lessons, Islamic schools only offer Islamic religious lessons and so on. However, the school does not require prospective students from other religions to pursue religion in accordance with the religious characteristics of the school concerned, this is as stated by Mr. Tata Wibawa as the Principal of SD Tarakanita Magelang. For example, if a Christian or Catholic school accepts non-Christian-Catholic students, it has no right to require or pressure 
parents to allow their non-Christian child to pursue or adhere to Christian-Catholicism. As has been conveyed by Mr. Tata Wibawa, namely at the time of acceptance of new students if there are students who are religious other than Christianity, SD Tarakanita provides a form of willingness that is first filled by parents about religious education subjects that will be given to students in accordance with the flag of SD Tarakanita which is a religious school with Catholic characteristics.

\section{The Obstacles of the Principal in the implementation of religious education in public religious elementary schools in Magelang city}

The obstacles faced by the principal in the implementation of teaching and learning activities of religious education subjects that are different from the religion that is characteristic of the school is the un availability of special room facilities that can be used in religious education learning activities. In connection with the absence of other means of space, other religious education learning activities must be carried out simultaneously with the hours of religious education learning that is characteristic of the school, while to arrange other learning schedules in lieu of not easy, this is related to school hours, other schedules of activities by students and teachers who teach subjects. The availability of teachers of certain religious teachers in some areas that are insufficient also becomes constrained. The school has difficulty finding educators for certain religious subjects, so that the religious subjects are not yet able to be given to students.

\section{Conclusion}

The implementation of learning on religious subjects in schools during both public schools and religiously characterized schools has been running well in accordance with the rules that have been imposed by the government as stated in article 12 paragraph (1) of Law No. 20 of 2003 on the National Education System (hereinafter referred to as UUSISDIKNAS) namely "Every student in each educational unit is entitled to religious education in accordance with the religion he embraces and is taught by religious educators." The role of the headmaster in religious public schools towards students who have different religions is to provide teachers for students who are religious other than the religion that is characteristic of the school, bring religious education teachers in accordance with the needs of the school based on the religion embraced by the students and provide a form of willingness that is first filled out by parents regarding religious education subjects that will be given to students in accordance with the school's religious characteristics.

The obstacles faced by the principal in the implementation of teaching and learning activities of religious education subjects that are different from the religions that are characteristic of the school are the un availability of special room facilities that can be used in religious education learning activities, setting the learning schedule of students and teachers because of the separation of hours of teaching and learning activities of students of other religions and the limited number of resources of teachers or educators of certain religious subjects. 


\section{References}

[1] E. Setiawan, "Kamus Besar Bahasa Indonesia (KBBI)." Mar. 30, 2021, [Online]. Available: https://kbbi.web.id/implementasi.

[2] S. Muntaha, "Apa itu Implenetasi? Inilah Pengertian, Tujuan, dan Konsepnya Lengkap." Mar. 30, 2020, [Online]. Available: https://www.alihamdan.id/implementasi/.

[3] N. Usman, Konteks implementasi berbasis Kurikulum: Bandung. CV Sinar Baru, 2002.

[4] W. contributors, "Pluralisme." Mar. 30, 2020, [Online]. Available: https://id.wikipedia.org/w/index.php?title=Pluralisme\&oldid=17594413.

[5] E. Damhuri, "Pancasila dan Pluralisme Agama." Mar. 30, 2017, [Online]. Available: https://www.republika.co.id/berita/jurnalisme-warga/wacana/17/10/20/oy2ya8440pancasila-dan-pluralisme-agama.

[6] L. J. Moleong, Metode penelitian kualitatif edisi revisi. Bandung: Remaja Rosdakarya, 2006. 